\title{
COMBINED DATING METHODS APPLIED TO BUILDING ARCHAEOLOGY: THE CONTRIBUTION OF THERMOLUMINESCENCE TO THE CASE OF THE BELL TOWER OF ST MARTIN'S CHURCH, ANGERS (FRANCE)
}

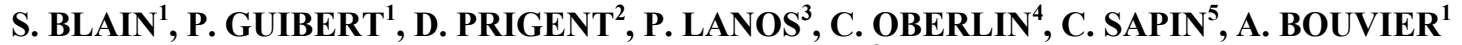 \\ and P. DUFRESNE ${ }^{3}$ \\ ${ }^{I} I R A M A T-C R P 2 A-U M R$ 5060, CNRS - Université de Bordeaux 3, Pessac, France \\ ${ }^{2}$ Service archéologique départemental de Maine-et-Loire, France \\ ${ }^{3}$ IRAMAT-CRP2A, Géoscience-Rennes-Université de Rennes 1, France \\ ${ }^{4}$ Centre de datation par le RadioCarbone, Université de Lyon 1, France \\ ${ }^{5}$ Laboratoire Artehis - UMR 5594, CNRS - Université de Bourgogne, Dijon, France
}

Received 26 April 2010

Accepted 15 October 2010

\begin{abstract}
St Martin's church, Angers, is emblematic of the problems raised in pre- $12^{\text {th }}$ century history of architecture.

In view of the importance of this building, it was necessary to attempt to define its dating and this study particularly focuses on its bell-tower. In addition to the conclusion resulting from the interpretation of written sources and typological criteria positioning the construction of the site at the beginning of the $11^{\text {th }}$ century, not only a significant number of ${ }^{14} \mathrm{C}$ dates were carried out on charcoals from the masonry structures, but also independent dating by archaeomagnetism and thermoluminescence were performed on bricks from the bell-tower. The whole results from these three different methods agree and indicate the lower level of the bell-tower was likely built in the $9^{\text {th }}$ century, disputing evidence to the theory of construction in the $11^{\text {th }}$ century of the church.

Presented here are the detailed results obtained from the thermoluminescence (TL) dating analysis.
\end{abstract}

Keywords: church, medieval, building archaeology, dating, radiocarbon, archaeomagnetism, luminescence.

\section{INTRODUCTION}

The limited knowledge of the early medieval period is mainly due to the restricted number of buildings that have come to light. Most pre-Romanesque buildings have been reused and incorporated into later phases, some abandoned and forgotten, some savaged and lost forever. The majority of buildings that survived from this period are religious ones. Indeed, in a world where social life revolved around religion, the church was one of the rare

Corresponding author: S. Blain e-mail: blain.sophie@gmail.com buildings considered important enough to be made of strong, non-perishable material such as stone or brick.

Religious sites in north-western France that have seen a continuity of durable settlement from the early medieval period to the present day include the collegial church of St Martin in Angers (Prigent and Hunot, 2006). This church constitutes a standing witness of the architecture of this period.

Because of its important place in architectural history, it is imperative that it is positioned as accurately as possible in the chronology of the history of art. Indeed it is often referred to in order to provide a chronological esti- 
mation of lesser-known buildings which display similar architectural features. One of these characteristics is the use of bricks in the masonry. In particular, they are often used to build up round-headed arches or to reinforce the frame of a wall with bonding courses; these features are believed to be inherited from Roman architecture.

In order to investigate further the chronology of this historical building and to consider the question of the origin of its building materials, the Groupe de Recherche Européen (GdRE), named "Terres cuites architecturales et Datation" and created in 2005 by archaeologist Ch. Sapin and physicist P. Guibert, became involved in the archaeological study of buildings such as St Martin's church. The aim was to bring together a series of different experts to form a multidisciplinary team. The building archaeological team comprised the Centre d'Etudes Médiévales and the Service départemental d'Archéologie de Maine-et-Loire, a history of art contribution from the Laboratoire de Médiévistique Occidentale de Paris (LAMOP) and the laboratories of absolute dating methods including Lyon for ${ }^{14} \mathrm{C}$ dating applied to charcoal from mortars, Rennes using archaeomagnetism techniques and Bordeaux performing dating by thermoluminescence.

This led to one of the first studies in France that entirely combines and correlates archaeological and archaeometric data on medieval buildings.

\section{Presentation of the site}

The church dedicated to Saint Martin is located in the city centre of the town of Angers, north-western France. It was built above remains of a Roman villa from the $3^{\text {rd }}$ century $\mathrm{AD}$ and a succession of later Christian and Merovingian oratories as suggested by a number of archaeological excavations carried out from 1902 to 2006 (Forsyth, 1953; Prigent and Hunot, 2006). The current church, recently restored, shows a plan which consists of a square aisled nave, a gothic chancel and a large salient transept with a bell-tower at the crossing (Fig. 2). The latter is built on four large piers and arches decorated with bricks in the masonry made of limestone moyen appareil (Mallet, 1984). Above it, a dome was likely added in a second phase (Fig. $\mathbf{1} \mathbf{a}, \mathbf{b}, \mathbf{c})$.

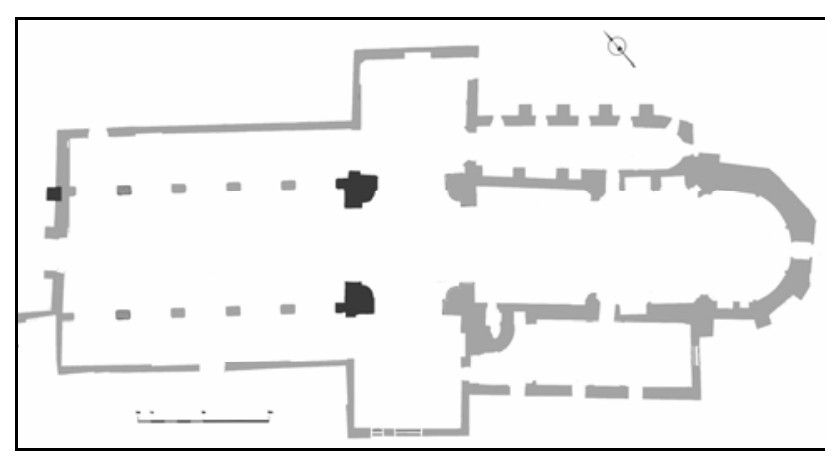

Fig. 2. Sample locations: charcoals from mortar sampled for the ${ }^{14} \mathrm{C}$ analysis and bricks sampled for the archaeomagnetism study come from the arches of the crossing-tower; bricks sampled for the TL study come from the two western piers supporting the above mentionea arches of the crossing-tower and one remaining buttress of the western façade (in dark grey on the plan; plan after G. Mester de Parajd ana M. Iseppi).
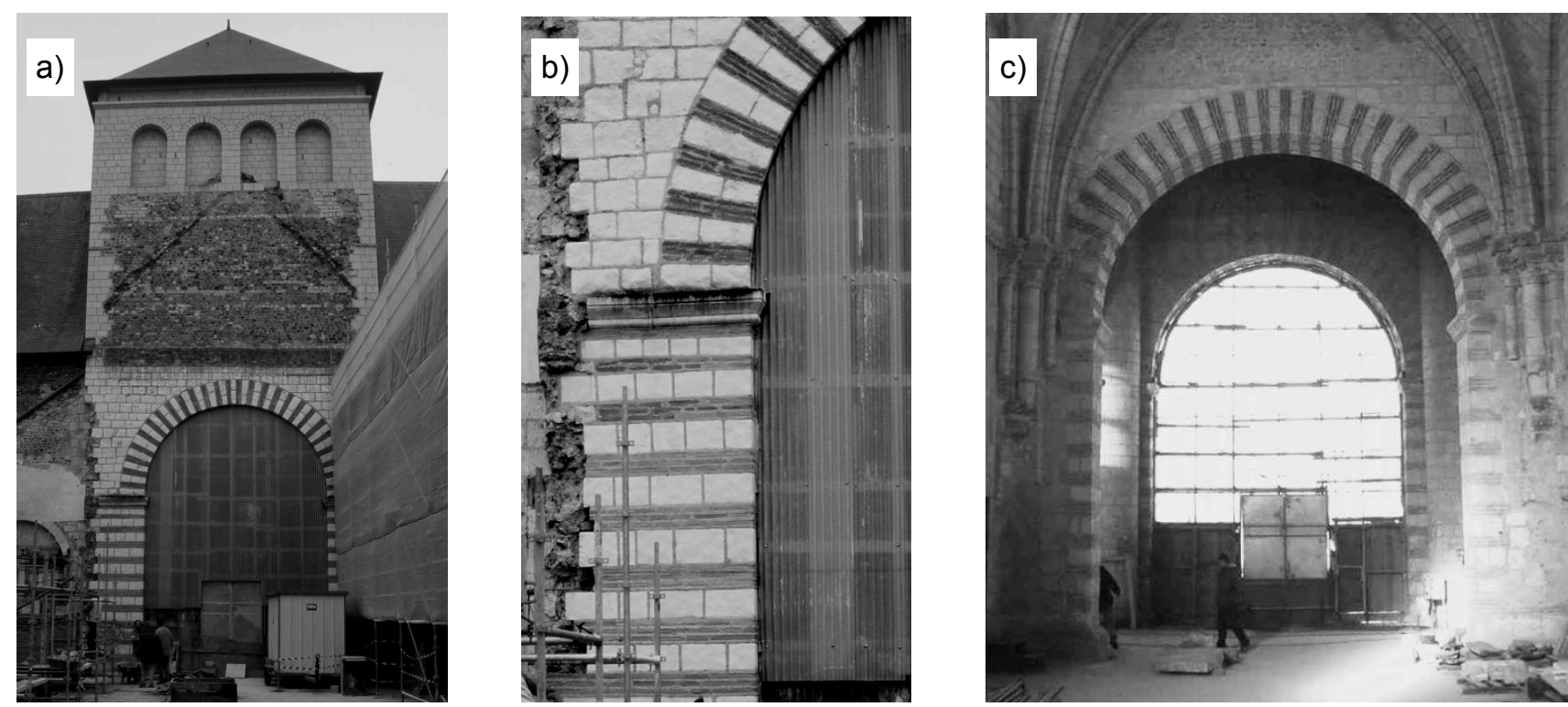

Fig. 1. a) View of the western arch of the crossing in the axis of the nave; b) detail of the external face of the north-western pier of the crossing; c) view of the crossing from the chancel (pictures Iramat-CRP2A taken during restoration works, December 2004). 


\section{Previous dating data}

The interpretation of written sources related to this building such as a pre-1020 charter suggests the construction of the church was the result of the intervention of the famous Count of Anjou, Fulk III Nerra (965/70-1040) in the beginning of the $11^{\text {th }}$ century.

On the basis of typological criteria, the capitals of the supports of the dome have been attributed to the beginning of the $11^{\text {th }}$ century.

Within the framework of the GdRE, further analytical dating was carried out on building materials from the bell-tower of the church. Samples of charcoal were taken from the mortar from the transept which is supposed to be prior to the crossing (Ly-3922) and from three different areas in the bell tower: one sample came from the arcade of the bell-tower (Ly-7857); another one was taken in the masonry above the arcades (Ly-10781) and the last one was sampled in the upper part of the bell-tower (Ly7856). They were analysed in the radiocarbon laboratory in Lyon and the calibration curve used was IntCal04. Results are reported in Table 1.

The 167 brick samples used for the archaeomagnetism study, carried out by the laboratory of the University of Rennes, came from the brick voussoirs of the west and south arcades of the bell-tower. The mean inclination estimated from the remnant magnetization of the bricks is reduced to Paris for comparison with the geomagnetic field calibration curve: the mean value obtained $70 \pm 2$ at Paris gives three ranges of dates: [640;794], [804; 897] and $[1645 ; 1801]$ AD.

Therefore, the written sources and typological data suggest an edification of the church and more specifically of the bell tower at the beginning of the $11^{\text {th }}$ century. However, on the basis of the dating results of ${ }^{14} \mathrm{C}$ applied to charcoals from the lower level of the crossing tower, it appears that the wood used to make the charcoal grew between the $8^{\text {th }}$ and the $10^{\text {th }}$ century. Archaeomagnetism provided two possible ranges of medieval dates for the dating of the brick manufacture.

In order to provide further chronological data from an independent method and to discriminate one interval for archaeomagnetism dating, luminescence dating was applied to ceramic building materials from the piers of the bell-tower. The objective is to shed light on the contro-

Table 1. Results of C14 dating applied on wood charcoals from the bell tower.

\begin{tabular}{lccc}
\hline Location & Sample & $\begin{array}{c}{ }^{14} \mathrm{C} \text { Age } \\
\text { (BP) }\end{array}$ & $\begin{array}{c}\text { Cal age (BP) } \\
94.4 \% \text { conf. int. }\end{array}$ \\
\hline $\begin{array}{l}\text { Transept } \\
\text { (prior to the bell-tower) }\end{array}$ & Ly-3922 & $1110 \pm 25$ & $(888-990) A D$ \\
\hline $\begin{array}{l}\text { Arcade of the bell-tower } \\
\text { Rubble masonry upper } \\
\text { the arcades }\end{array}$ & Ly-7857 & $1202 \pm 34$ & $(735-942) A D$ \\
\hline $\begin{array}{l}\text { Upper storey of the } \\
\text { bell-tower }\end{array}$ & Ly-7856 & $950 \pm 40$ & $(1024-1187) A D$ \\
\hline
\end{tabular}

versy surrounding the origin of the building and consequently to verify whether Fulk Nerra's intervention encompassed the bell-tower of the church.

\section{THERMOLUMINESCENCE}

The relevance of luminescence dating to medieval building archaeology has been already established (Guibert et al., 1998; Gallo et al., 1999; Bailiff and Holland, 2000; Vieillevigne et al., 2007; Bailiff, 2007; Blain et al., 2007; Blain et al., 2010). Presented here are the methodological specificities related to the luminescence properties of the St Martin's materials.

\section{Samples}

The brick sampling strategy was designed with archaeologists according to the historical and archaeological questions to be answered (Fig. 2). Multiple samples were taken from the selected areas of masonry in order to check whether the samples are contemporaneous or, on the contrary, to show the existence of reused materials.

Six samples of bricks were taken with a chisel and a hammer from the two western piers of the crossing tower between the cut stones (referenced TL_9456, TL_9657, TL_9459, TL_9461 and TL_9472) and from the western façade (referenced TL_9462).

\section{Principle}

The principle and general aspects of thermoluminescence (TL) dating are described in detail by Aitken (1985).

The stimulated luminescence is based on the property of irradiated crystals to emit light as a result of the application of external stimulation such as heat or light. This light emission results from the cumulative effects of natural irradiation on the composite crystalline materials that are typically found in ceramic materials. The irradiation is due to the presence of naturally occurring radionuclides and the effects of cosmic rays. During ionisation, electrons are liberated from their parent atom in the crystal and are trapped in the crystal defects. The number of trapped electrons increases with the time of irradiation. The application of heat can provide sufficient energy to liberate the trapped electrons, the recombination of which with holes results in the emission of light. The intensity of light emission is proportional to the number of trapped electrons and ultimately to the amount of radiation received. This process is called thermoluminescence (TL).

The last archaeological firing of the ceramics empties the traps of the crystal filled previously (known as a zeroing event). The process of electron trapping recommences after firing allowing the subsequent measurement of luminescence which results only from the irradiation after the zeroing event. The quantity of absorbed and stored energy is called paleodose and is proportional to the time elapsed since firing and the radioactive dose rate. During 
laboratory experimentation traps are emptied by the application of heat which as previously stated results in the further emission of light.

The luminescence age was calculated using the age equation below:

TL age $(\mathrm{yrs})=$ paleodose $(\mathrm{Gy}) /$ annual dose $(\mathrm{Gy} / \mathrm{yr})(2.1)$

\section{Method}

A preliminary study to evaluate which luminescence dating technique is the most appropriate consists of characterising the material to be dated. This analysis of the grains present within the ceramic material involves the identification of their nature, their quantification and their morphology. This can be done by optical microscopy in transmitted polarised light and Scanning Electron Microscopy - Back-Scattered Electron imagery.

Due to the particularly fine fabric of the bricks from St Martin's, it was decided to evaluate the paleodose using the polymineral fine grain technique, which consists of a mixture of quartz, feldspars and other aluminosilicates in the grain size range of 3 to $12 \mu \mathrm{m}$. The experimental protocol used was based on an additive procedure carried out on naturally irradiated aliquots which were given additional laboratory doses, followed by regeneration experiments on annealed aliquots (regenerated TL; Guibert et al., 1996; Roque et al., 2004, Vieillevigne et al., 2007). The equivalent dose was measured by integrating the TL curves between 280 and $500^{\circ} \mathrm{C}$ and calculated by non-linear fitting of TL-dose response curves. The data obtained with the regeneration procedure were used to define the growth function, which was fitted to the additive dose data points according to a slide method (Guibert et al, 1996). Furthermore, the choice of the polymineral fine grain technique required further tests to be carried out to check the fading evolution of luminescence.

The annual dose was determined using different techniques. The components of the annual dose due to natural radioactive sources in the bricks were calculated using concentration values of lithogenic radionuclides determined by low-background gamma spectrometry measurements (Guibert and Schvoerer, 1991; Guibert et al., 2009) on powdered brick samples. Alpha and beta dose rates were calculated using the conversion factors by Adamiec and Aitken (1998). The gamma and cosmic dose rates were determined by in situ dosimetry $\left(\mathrm{CaSO}_{4}: \mathrm{Tm}\right)$. The capsules were left for 6 months in the holes left by the samples in the wall. 5 aliquots of the dosimeters have been measured by TL with the same equipment than for paleodose determination. A first series of measurements consists of reading the "natural" signal registered by the dosimeters during their exposure time. After zeroing, the 5 aliquots are given increasing artificial doses with a ${ }^{90} \mathrm{Sr}^{90} \mathrm{Y} \beta$-source and the natural signals are compared with the growth function to determine the environmental dose rate.
A standard value of $5 \pm 3 \%$ was assigned to the average moisture content of bricks, on the basis of relatively dry conditions and good drainage where capillary effects were judged to have been insignificant.

\section{Instrumentation and techniques}

After crushing and sieving samples of bricks, grains whose diameter is less than $40 \mu \mathrm{m}$ were extracted and etched by $\mathrm{HCl}(1 \mathrm{M})$ for $100 \mathrm{~min}$, by $\mathrm{H}_{2} \mathrm{O}_{2}(72 \mathrm{~h})$ and then by a combination of $\mathrm{HF}(0.5 \mathrm{M})$ and $\mathrm{HCl}(1 \mathrm{M})$ for $100 \mathrm{~min}$. The $3-12 \mu \mathrm{m}$ grain-size fraction was selected by successive sedimentations in acetone. Aliquots of this fine grain mixture were deposited onto $10 \mathrm{~mm}$ diameter brass discs ( $\sim 1 \mathrm{mg}$ of material per aliquot) by sedimentation process. The TL curves were recorded from room temperature to $500^{\circ} \mathrm{C}$ using an automatic TL reader built in the laboratory of Bordeaux. A $190^{\circ} \mathrm{C}$ preheat was held for $2 \mathrm{~min}$ to reduce possible thermally unstable components of the TL signal. The TL emissions were detected by an EMI 9813/QKA photomultiplicator tube through a set of optical filters composed of 2 Schott BG12 (spectral window 350-470 nm). Irradiations were performed using ${ }^{a}{ }^{90} \mathrm{Sr}^{90}{ }^{90} \mathrm{Y} \beta$-source (delivering a dose-rate of $0.079 \mathrm{~Gy} / \mathrm{s}$ in September 2007) and a ${ }^{241} \mathrm{Am} \alpha$-source (delivering an alpha equivalent dose rate of $0.17 \mathrm{~Gy} / \mathrm{s}$ ).

The low-background gamma spectrometry measurements were performed with a high-purity Ge well detector (Canberra-Eurisys Mesures, EGPC 200 P17). For the environmental contribution of the annual dose, the dosimeter capsules (placed in a $2 \mathrm{~mm}$ thick-wall brass container) containing $\mathrm{CaSO}_{4}: \mathrm{Tm}$ phosphors were placed in the remaining part of the bricks sampled or in the closest brick to the sampled ones in order to respect as close as possible the irradiation geometry of the samples of brick removed.

\section{Paleodose determination}

Since feldspars were part of the polymineral mixture, a study of the stability of the TL signals was necessary (Sanderson, 1988; Tyler and McKeever, 1988; Visocekas et al, 1994; Zink, 1996). The experimental results showed the existence of a short term fading. Indeed after laboratory irradiation and preheating at $190^{\circ} \mathrm{C}$ for $2 \mathrm{~min}$, the signal tended to initially slightly decrease and then to become stable after some 100 hours.

For all samples like in Fig. 3, the decay of the TL signals, measured for 84 days, were found closer to an exponential function evolving asymptotically to a stable level (curve b) than the logarithmic function generally used when a tunnel effect recombination arises with pure feldspar phases (curve a). Indeed the Chi 2 test calculated between the experimental data and either the exponential model with stabilisation or the logarithmic one is more significant (at $80 \%$ of probability) for the first model than the latter. The palaeodose values were therefore adjusted to take account of fading by applying a correction factor 


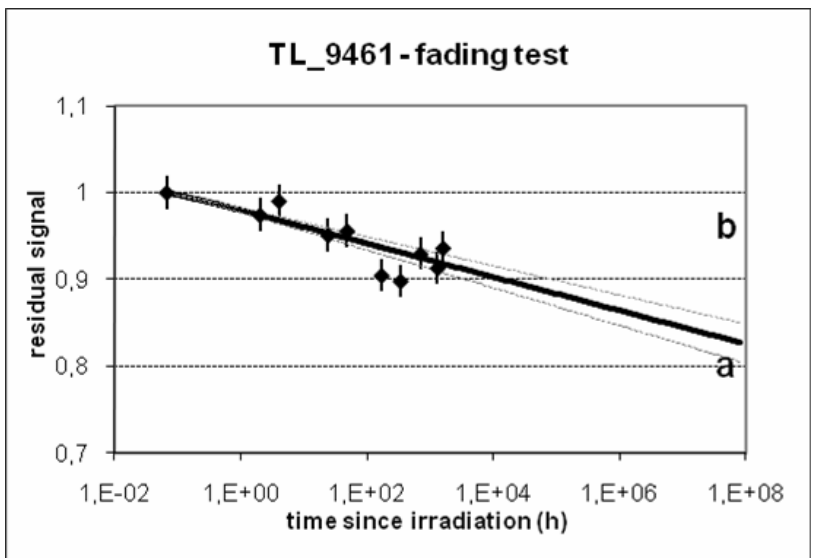

Fig. 3. Sample TL_9461: Concentration of radionuclides measured by low-background gamma spectrometry with powdered bricks, and calculated mean value for $U\left({ }^{226} R a\right)$. Uncertainties are one standard deviation.

to the mean paleodose, corresponding to the mean value of the residual signals recorded from a seven-day delay $(\approx 0.88-0.98)$.

Furthermore, it is necessary to determine the $\alpha$ dose contribution to the paleodose. This so-called $k$-value determination is carried out on fine grains heated in order to remove natural TL signals. Some aliquots of the annealed material are given an alpha dose equal to ca. ten times the beta equivalent dose already determined. Others are given increasing beta doses that define a growth curve (TL intensity versus beta dose); the alpha equivalent dose is deduced from the intersection of TL intensity of alphadosed aliquots, with the $\beta$-dose growth curve. $k$-value is then known by the ratio of $\alpha$-equivalent dose on $\beta$-equivalent dose.

The results of paleodose measurements before and after correction of the fading, $k$-value determination and associated standard deviation are reported in Table 2.

\section{Annual dose determination}

The concentrations of $\mathrm{K}, \mathrm{U}$ and Th measured in powdered ceramic using high resolution gamma ray spectrometry are given in Table 3 .

Disequilibria of U-series in brick samples were found, as shown by small but significant discrepancies between $\mathrm{U}\left({ }^{238} \mathrm{U}\right)$ and $\mathrm{U}\left({ }^{226} \mathrm{Ra}\right)$ (Fig. 4).
Apart from the particular case of radon escape, generally in porous media, disequilibria are a consequence of changes in the concentration of long-lived nuclides, due to the solubility and thus the mobility of certain species such as uranium $\left({ }^{234} \mathrm{U},{ }^{235} \mathrm{U},{ }^{238} \mathrm{U}\right.$ in the redox state $\left.+\mathrm{VI}\right)$ and/or radium $\left({ }^{226} \mathrm{Ra}\right.$ ) (Gascoyne, 1982), transported or leached by soil water. In contrast, thorium is considered to be geochemically stable because of its very low solubility. For buried systems, affected by soil water circulation, the main point for paleodosimetric considerations and annual dose rate corrections is to determine what element had been varying through time, $\mathrm{U}$ or Ra. In the

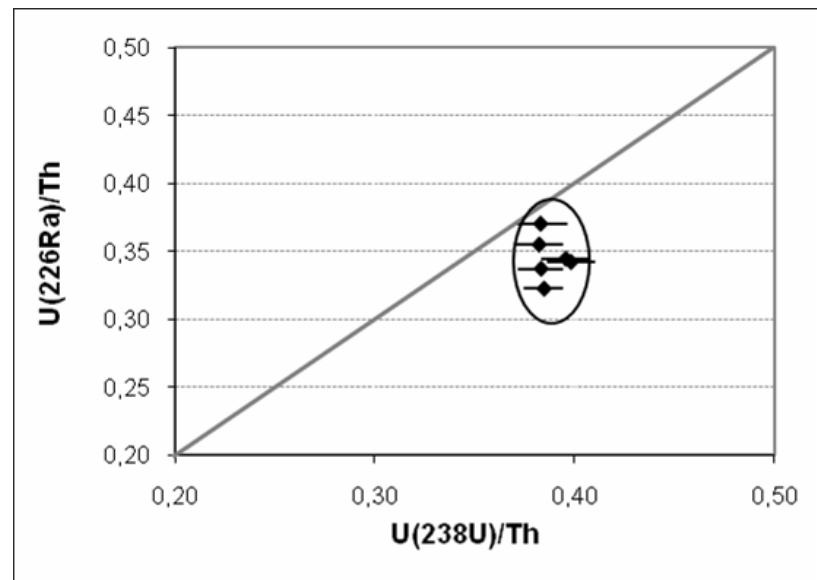

Fig. 4. Study of the disequilibrium of the U-series by the analysis of the content ratios $U\left({ }^{238} \mathrm{U}\right) / T h$ and $U\left({ }^{226} R a\right) / T h$

Table 2. Paleodose value $(P)$ after correction of the fading, expressed in Gray, and statistical standard deviations determined from TL experiments; $k$-value is the alpha attenuation factor.

\begin{tabular}{lccc}
\hline Sample & $\begin{array}{c}\mathrm{P}(\mathrm{Gy}) \text { non corrected of } \\
\text { the fading }\end{array}$ & $\begin{array}{c}\mathrm{P}(\mathrm{Gy}) \text { corrected of } \\
\text { the fading }\end{array}$ & k-value \\
\hline TL_9456 & $10.47 \pm 0.41$ & $10.91 \pm 0.47$ & $0.120 \pm 0.007$ \\
\hline TL_9457 & $10.30 \pm 0.59$ & $10.67 \pm 0.62$ & $0.107 \pm 0.002$ \\
\hline TL_9459 & $10.77 \pm 0.47$ & $11.66 \pm 0.53$ & $0.113 \pm 0.005$ \\
\hline TL_9461 & $9.86 \pm 0.47$ & $10.76 \pm 0.51$ & $0.107 \pm 0.006$ \\
\hline TL_9462 & $9.49 \pm 0.46$ & $10.99 \pm 0.60$ & $0.110 \pm 0.002$ \\
\hline TL_9472 & $12.10 \pm 0.59$ & $12.38 \pm 0.64$ & $0.117 \pm 0.002$ \\
\hline
\end{tabular}

Table 3. Concentration of radionuclides measured by low-background gamma spectrometry with powdered bricks, and calculated mean value for $U\left({ }^{226} R a\right)$. Uncertainties are one standard deviation.

\begin{tabular}{|c|c|c|c|c|c|c|c|}
\hline Sample & $\begin{array}{c}\mathrm{K}_{\text {ceram. }} \\
(\%)\end{array}$ & $\mathrm{U}\left({ }^{238} \mathrm{U}\right)$ ceram $(\mathrm{ppm})$ & $\begin{array}{c}\mathrm{U}\left({ }^{226} \mathrm{Ra}\right) \\
\text { ceram }(\mathrm{ppm}) \text { measured }\end{array}$ & $\begin{array}{l}\mathrm{U}\left({ }^{226} \mathrm{Ra}\right) \text { ceram }(\mathrm{ppm}) \\
\text { calculated mean }\end{array}$ & Th ceram. (ppm) & $\mathrm{U}\left({ }^{210} \mathrm{~Pb}\right)$ ceram $(\mathrm{ppm})$ & ${ }^{210} \mathrm{~Pb} /{ }^{226} \mathrm{Ra}$ \\
\hline TL_9456 & $2.87 \pm 0.04$ & $9.34 \pm 0.26$ & $8.23 \pm 0.07$ & $7.91 \pm 0.07$ & $24.39 \pm 0.22$ & $7.35 \pm 0.35$ & 0.89 \\
\hline TL_9457 & $2.94 \pm 0.04$ & $9.59 \pm 0.27$ & $8.24 \pm 0.07$ & $7.86 \pm 0.07$ & $24.08 \pm 0.22$ & $7.50 \pm 0.39$ & 0.91 \\
\hline TL_9459 & $2.74 \pm 0.04$ & $9.11 \pm 0.31$ & $8.80 \pm 0.07$ & $8.72 \pm 0.07$ & $23.79 \pm 0.22$ & $9.42 \pm 0.50$ & 1.07 \\
\hline TL_9461 & $2.69 \pm 0.03$ & $9.32 \pm 0.27$ & $8.11 \pm 0.06$ & $7.77 \pm 0.07$ & $23.54 \pm 0.19$ & $8.48 \pm 0.42$ & 1.05 \\
\hline TL_9462 & $2.77 \pm 0.04$ & $9.27 \pm 0.29$ & $8.61 \pm 0.07$ & $8.43 \pm 0.07$ & $24.27 \pm 0.21$ & $9.31 \pm 0.47$ & 1.08 \\
\hline TL_9472 & $2.86 \pm 0.04$ & $9.46 \pm 0.23$ & $7.94 \pm 0.06$ & $7.52 \pm 0.07$ & $24.61 \pm 0.19$ & $7.51 \pm 0.31$ & 0.95 \\
\hline
\end{tabular}


present case of St Martin's church, no movement of water responsible of changes in $\mathrm{U}$ or $\mathrm{Ra}$ can be envisaged since the edification, thus, the observed disequilibrium is interpreted as the result of a disequilibrium that occurs in the clay material used for the manufacture of bricks. A statistical method, already detailed (Guibert et al., 1997; 2009), allows us to evaluate which element was the most mobile. The ideas that underlie the method are as follows:

- at any site (here the clay raw material sites are concerned), there are wide spatial variations in the extent of soil water circulation;

- the extent of change in mobile element concentration in clay is in relation with the importance of soil water circulation;

- thus the most mobile element that alters sediments produces also the most variable content among a collection of samples.

Practically a variance study of distribution of $U$ and $\mathrm{Ra}$ contents can show which one is the most variable, and is therefore at the origin of disequilibrium.

In the present case of St Martin's church, the $\mathrm{U}\left({ }^{226} \mathrm{Ra}\right) / \mathrm{Th}$ ratio is more variable than the $\mathrm{U}\left({ }^{238} \mathrm{U}\right) / \mathrm{Th}$ ratio, which is easily noticeable in Fig. 6. As the most altered element by leaching in the raw material is expected to have the largest variability in content, the present disequilibrium can be interpreted as a consequence of a $\mathrm{Ra}$ elimination occurred in the clay before the brick manufacture.

It can be considered that the age of material (around 1100 a) and the half-life of ${ }^{226} \mathrm{Ra}(1602$ a) have the same order of magnitude. Radium concentration gradually grows as far as its parent decays, from an initial value (when the bricks were fired) to the current ones measured by gamma spectroscopy.

To determine the mean value of radium concentration $\mathrm{U}\left({ }^{226} \mathrm{Ra}\right)$ in each sample, the following simplifying assumption was stated: same activity for ${ }^{238} \mathrm{U},{ }^{234} \mathrm{U}$ and ${ }^{230} \mathrm{Th}$. Details of calculation can be explained as follow.

$\mathrm{U}\left({ }^{226} \mathrm{Ra}\right)$ and $\mathrm{U}\left({ }^{238} \mathrm{U}\right)$ are the apparent concentrations in ${ }^{238} \mathrm{U}$ series measured by gamma spectroscopy from immediate daughters of ${ }^{226} \mathrm{Ra}$ and ${ }^{238} \mathrm{U}$ (and ${ }^{235} \mathrm{U}$ ), respectively.

$\mathrm{Ra}_{0}$, represents the initial activity in radium, $\mathrm{U}_{0}$ the initial activity in uranium, the latter being the same as today $\left(\mathrm{U}=\mathrm{U}_{0}\right)$.

Through the time elapsed since manufacture, radium activity varies according to:

$\mathrm{Ra}(\mathrm{t})=\mathrm{Ra}_{0}+\left(\mathrm{U}-\mathrm{Ra}_{0}\right)\left(1-\exp \left(-\ln (2) \mathrm{t} / \mathrm{T}_{226}\right)\right)$

When $t$ is equal to the age of bricks, $T_{226}$ is the half life of ${ }^{226} \mathrm{Ra}$, $\mathrm{Ra}$ is the actual value of radium activity so that the previous expression becomes:

$$
\mathrm{Ra}=\mathrm{Ra}_{0}+\left(\mathrm{U}-\mathrm{Ra}_{0}\right)\left(1-\exp \left(-\ln (2) \text { age } / \mathrm{T}_{226}\right)\right)
$$

then $\mathrm{Ra}_{0}$ can be given from the measured values of $\mathrm{U}$ and $\mathrm{Ra}$, and age of samples:
$\mathrm{Ra}_{0}=\mathrm{Ra} \exp \left(\ln (2) \mathrm{age} / \mathrm{T}_{226}\right)+\mathrm{U}\left(1-\exp \left(\ln (2)\right.\right.$ age $\left.\left./ \mathrm{T}_{226}\right)\right)$

and the mean value of radium concentration $\mathrm{Ra}^{*}$ is given by integration of [1] from $\mathrm{t}=0$ to $\mathrm{t}=$ age:

$\mathrm{Ra}^{*}=\mathrm{U}-\left\{\left(\mathrm{U}-\mathrm{Ra}_{0}\right)\left(1-\exp \left(-\ln (2)\right.\right.\right.$ age $\left.\left./ \mathrm{T}_{226}\right)\right) / \ln (2)$ age /

$\left.\mathrm{T}_{226}\right\}$

The calculated mean values of $U\left({ }^{226} \mathrm{Ra}\right)$ are listed in Table 3.

The alpha and beta dose rates were evaluated from analytical data. In the case of a disequilibrium due to an ancient depletion of radium, the $\mathrm{U}$ series nuclides are divided into the following groups:

- from ${ }^{238} \mathrm{U}$ to ${ }^{230} \mathrm{Th}$ and ${ }^{235} \mathrm{U}-{ }^{207} \mathrm{~Pb}$, the concentration of which is given by $\left.\mathrm{U}^{238} \mathrm{U}\right)$,

- from ${ }^{226} \mathrm{Ra}$ to ${ }^{206} \mathrm{~Pb}$, the concentration of which is given by $\mathrm{U}\left({ }^{226} \mathrm{Ra}\right)$.

In this case, as the mean value of the ratio ${ }^{210} \mathrm{~Pb} /{ }^{226} \mathrm{Ra}$ is close to 1 , therefore it has been considered the series portion, including ${ }^{222} \mathrm{Rn}$, is in equilibrium with ${ }^{226} \mathrm{Ra}$.

The corresponding revisited annual dose factors for the U series corrected following this model are reported in (Table 4) and are calculated from Adamiec and Aitken's data (1998) (Table 5).

\section{Ages calculation}

The final individual dates of manufacture, showed in Table 6, range from $735 \pm 83$ AD to $928 \pm 65$ AD. Since the dates as a group appear to be homogeneous $\left(\chi^{2}=5.56\right.$ for a range at $80 \%$ of likeliness: $1.61-9.24)$, it is allowed to consider them as contemporaneous and to calculate their mean date which situates the firing of the bricks in $851 \pm 60 \mathrm{AD}$ (at $1 \sigma)$.

\section{DISCUSSION}

TL dating on bricks (range [791; 911] AD) is in good agreement with those obtained with ${ }^{14} \mathrm{C}$ applied on charcoals from mortars for the arches of the bell-tower (735$942 \mathrm{AD})$ and with the dating archaeomagnetism range [824; 924] AD obtained for bricks of this structure (Fig. 5), which allow validating all the dating results.

Table 4. Annual dose factors used to calculate the alpha and beta dose rates in bricks in case of a disequilibrium originated in radium movement.

\begin{tabular}{cccccc}
\hline \multirow{2}{*}{$\begin{array}{c}\text { Radio- } \\
\text { element }\end{array}$} & $\begin{array}{c}\text { content } \\
\text { unit }\end{array}$ & \multicolumn{2}{c}{$\begin{array}{c}\text { annual dose factor (Gy/ka } \\
\text { per content unit) }\end{array}$} & \multirow{2}{*}{$\begin{array}{c}\text { corresponding } \\
\text { sets of isotopes }\end{array}$} \\
\cline { 3 - 5 } & alpha & beta & gamma & \\
\hline $238 \mathrm{U}$ & $\mathrm{ppm}$ & 0.956 & 0.0604 & 0.0038 & $\begin{array}{c}{ }^{238} \mathrm{U}-230 \mathrm{Th} \\
\left({ }^{235} \mathrm{U}-207 \mathrm{~Pb}\right)\end{array}$ \\
\hline${ }^{226} \mathrm{Ra}$ & $\mathrm{ppm}$ & 1.824 & 0.0856 & 0.1090 & ${ }^{226} \mathrm{Ra}-{ }^{206} \mathrm{~Pb}$ \\
\hline $\mathrm{Th}$ & $\mathrm{ppm}$ & 0.732 & 0.0273 & 0.0476 & ${ }^{232} \mathrm{Th}-{ }^{208} \mathrm{~Pb}$ \\
\hline $\mathrm{K}$ & $\%$ & - & 0.782 & 0.243 & ${ }^{40} \mathrm{~K}-40 \mathrm{Ca},{ }^{40} \mathrm{Ar}$ \\
\hline
\end{tabular}


Table 5. Alpha contribution to the dose-rate (mGy/yr) and beta dose rate (mGy/yr) determined from gamma-spectrometry measurements (MEAS) and from after correction according to the model of Ra depletion (CORR). Combined gamma and cosmic dose rate (lenv, expressed in mGy/yr) measured using dosimeter capsules and the total annual dose (ltot) determined by the laboratory of Bordeaux (mGy/yr) before (MEAS) and after (CORR) correction of the Ra depletion model. It can be noticed the corrections due to the model of Ra depletion are minor. Uncertainties are one standard deviation. They include statistical and systematic components.

\begin{tabular}{|c|c|c|c|c|c|c|c|}
\hline Sample & $\begin{array}{c}\text { I } \alpha_{\text {ceram MEAS }} \\
\text { (mGy/yr) }\end{array}$ & $\begin{array}{c}\alpha_{\text {ceram CORR }} \\
\text { (mGy/yr) }\end{array}$ & $\begin{array}{c}\text { I } \beta_{\text {ceram MEAS }} \\
(\mathrm{mG} \text { Gyr) }\end{array}$ & $\begin{array}{c}\text { I } \beta_{\text {ceram CORR }} \\
\text { (mGy/yr) }\end{array}$ & $\begin{array}{c}\text { lenv } \\
\text { (mGy/yr) }\end{array}$ & $\begin{array}{l}\text { Itotal MEAS } \\
\text { (mGy/yr) }\end{array}$ & $\begin{array}{l}\text { Itotal CORR } \\
\text { (mGy/yr) }\end{array}$ \\
\hline TL_9456 & $4.78 \pm 0.33$ & $4.71 \pm 0.32$ & $3.98 \pm 0.14$ & $3.95 \pm 0.14$ & $1.45 \pm 0.04$ & $10.21 \pm 0.53$ & $10.11 \pm 0.53$ \\
\hline TL 9457 & $4.25 \pm 0.18$ & $4.18 \pm 0.17$ & 4.040 .14 & $4.01 \pm 0.14$ & $1.45 \pm 0.04$ & $9.74 \pm 0.44$ & $9.64 \pm 0.44$ \\
\hline TL_9459 & $4.54 \pm 0.26$ & $4.52 \pm 0.26$ & $3.90 \pm 0.13$ & $3.89 \pm 0.13$ & $1.45 \pm 0.04$ & $9.89 \pm 0.46$ & $9.86 \pm 0.46$ \\
\hline TL 9461 & $4.19 \pm 0.28$ & $4.12 \pm 0.28$ & $3.81 \pm 0.13$ & $3.78 \pm 0.13$ & $1.35 \pm 0.04$ & $9.35 \pm 0.46$ & $9.25 \pm 0.46$ \\
\hline TL 9462 & $4.45 \pm 0.18$ & $4.41 \pm 0.18$ & $3.93 \pm 0.14$ & $3.91 \pm 0.14$ & $1.38 \pm 0.04$ & $9.76 \pm 0.42$ & $9.71 \pm 0.42$ \\
\hline TL 9472 & $4.61 \pm 0.18$ & $4.51 \pm 0.18$ & $3.96 \pm 0.14$ & $3.92 \pm 0.13$ & $1.30 \pm 0.04$ & $9.88 \pm 0.43$ & $9.74 \pm 0.42$ \\
\hline
\end{tabular}

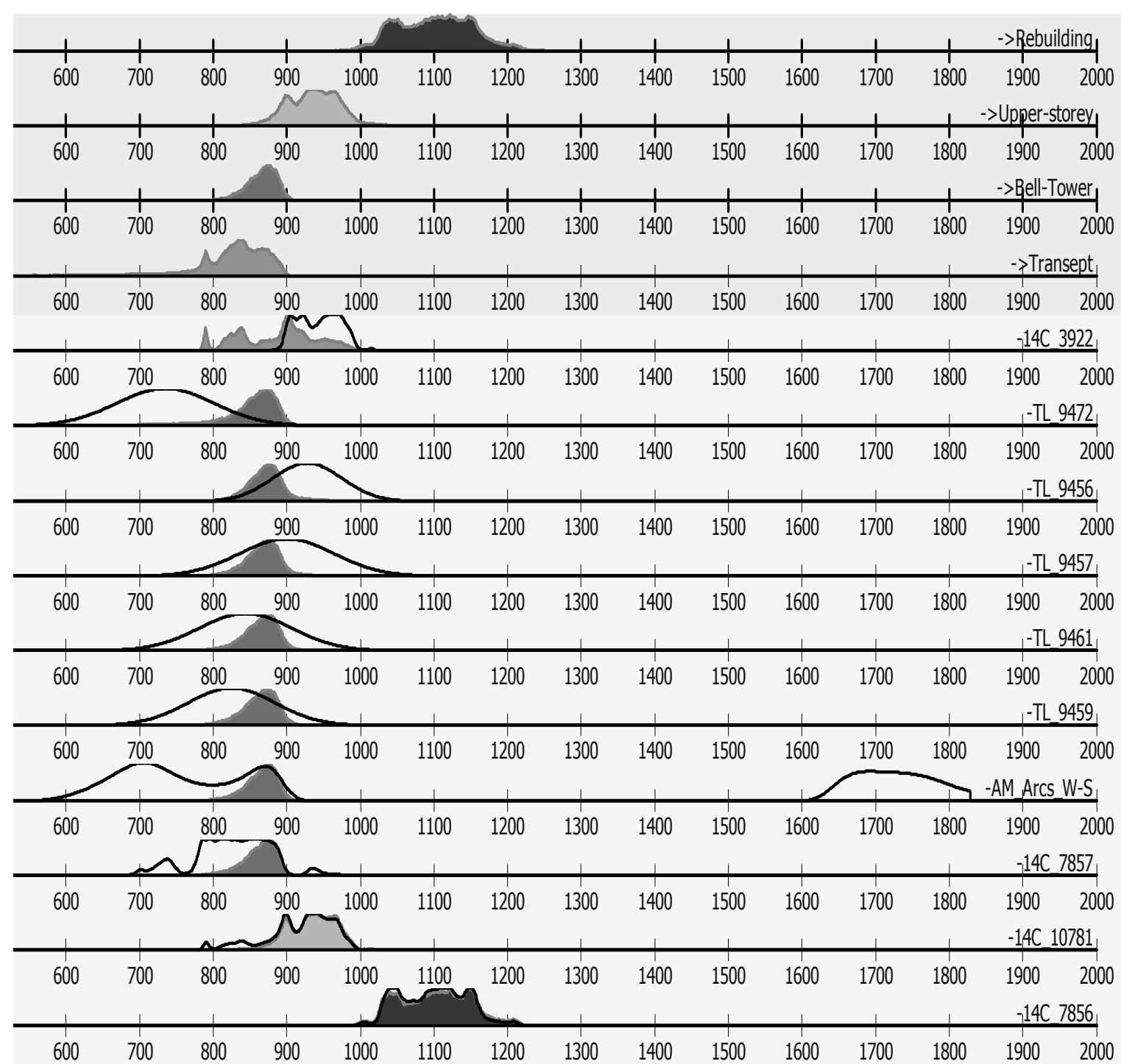

Fig. 5. Results of the individual $T L, C 14$ and archaeomagnetism dating for the bell tower and overall means for each building phases of the structure. The lined curves and the grey plain curves represent the individual dates respectively before and after application of the models of stratigraphical constraints and events. 


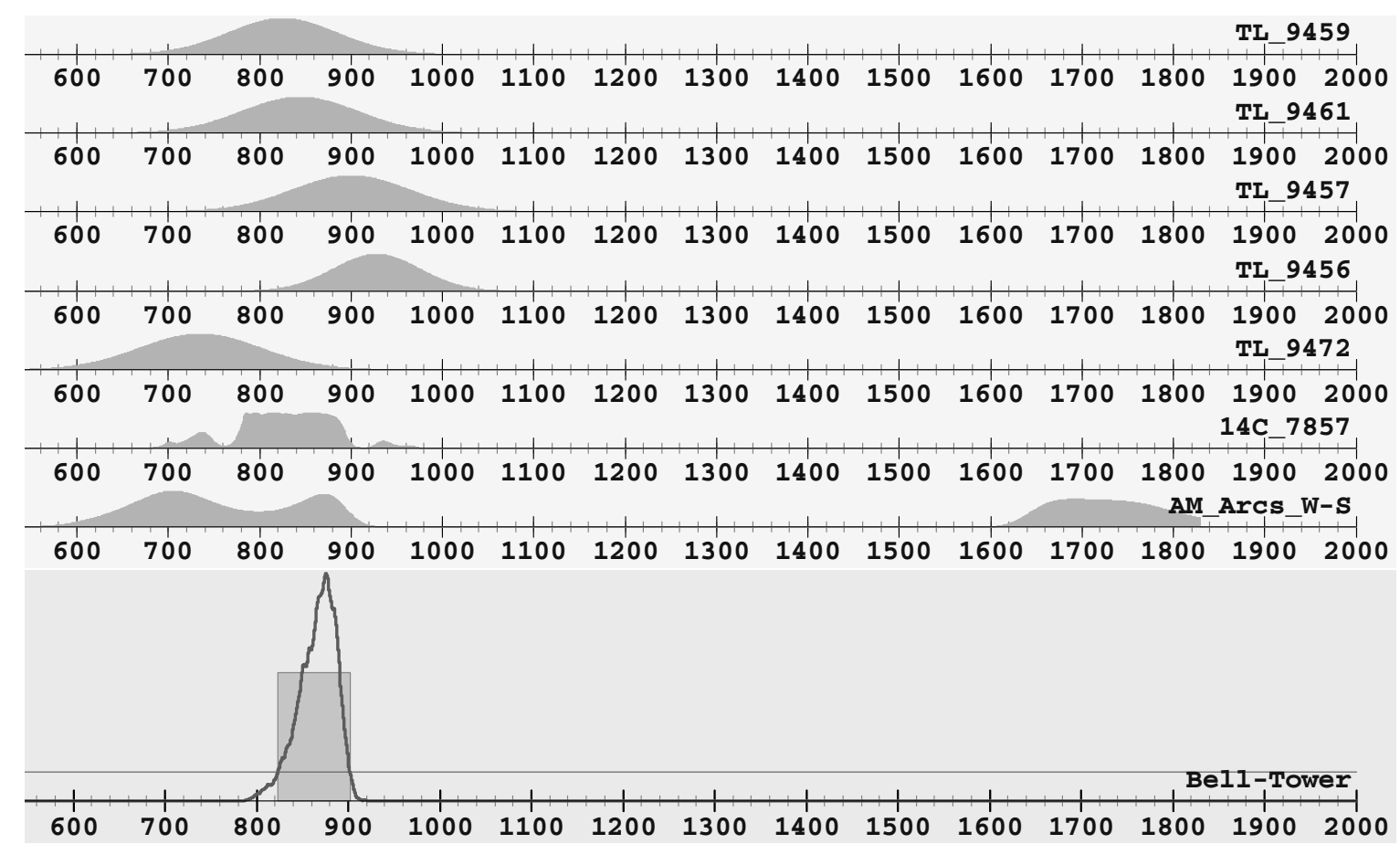

Fig. 6. Results of the individual TL ,C14 and archaeomagnetism dating for the lower level of the bell tower and its overall mean.

Table 6. Individual ages and dates calculated for each samples. Ages are given before 2007. Uncertainties are one standard deviation.

\begin{tabular}{ccccc}
\hline Sample & $P(G y)$ & $\begin{array}{c}\text { Itotale } \\
(\mathbf{m G y} / \mathbf{y r})\end{array}$ & $\begin{array}{c}\text { Age (yrs) } \pm 1 \sigma_{\text {tot }} \\
\left(\boldsymbol{\sigma}_{\text {stat }}\right.\end{array}$ & $\begin{array}{c}\text { Dates (AD) } \\
\mathbf{\pm 1} \sigma_{\text {tot }}\end{array}$ \\
\hline TL_9456 & $10.91 \pm 0.47$ & $10.11 \pm 0.53$ & $1079 \pm 65(47)$ & $928 \pm 65$ \\
\hline TL_9457 & $10.67 \pm 0.62$ & $9.64 \pm 0.44$ & $1107 \pm 79(64)$ & $900 \pm 79$ \\
\hline TL_9459 & $11.66 \pm 0.53$ & $9.86 \pm 0.46$ & $1182 \pm 79(59)$ & $825 \pm 79$ \\
\hline TL_9461 & $10.76 \pm 0.51$ & $9.25 \pm 0.46$ & $1163 \pm 82(63)$ & $844 \pm 82$ \\
\hline TL_9462 & $10.99 \pm 0.60$ & $9.71 \pm 0.42$ & $1132 \pm 81(63)$ & $875 \pm 80$ \\
\hline TL_9472 $12.38 \pm 0.64$ & $9.74 \pm 0.42$ & $1272 \pm 83(66)$ & $735 \pm 83$ \\
\hline
\end{tabular}

This convergence allows combining all the dating results in order to provide a more accurate date for the building of the arches of the bell-tower. Using a Bayesian statistical approach developed in Lanos' software RenDate (Lanos, 2001, 2004; Sapin et al., 2008; Cassen et al., 2009), the final date for the bell-tower is estimated to [825-900] AD at the 95\% level of confidence (Fig. 6).

\section{CONCLUSION}

This study is a good example of the relevance of absolute dating methods and more specifically of luminescence dating applied to building archaeology. Moreover it completes the previous works of Vieillevigne et al. (2007), Bailiff (2007) and Blain et al. (2007, 2010) on the utility of luminescence dating of Ceramic Building Materials in the study of historical buildings.
In this study the edification date for the tower-bell of the church of St Martin was defined. Indeed if the manufacture of the materials is considered to be contemporary with the construction of the building, placing the building of the church in the $9^{\text {th }}$ century, this presents opposing evidence to the theory of Fulk Nerra being responsible for the whole construction.

Therefore this work shows the importance of being cautious towards written records and their chronological interpretation to a specific architectural structure. Such a contribution in the chronology of one building questions consequently the dating of other buildings displaying similar architectural and artistic features. It can be seen here the importance of such a study to the whole history of architecture for the period concerned.

\section{ACKNOWLEDGEMENT}

This research was supported by the CNRS, Department of Human and Social Sciences within the frame of the GdRE (Groupe de Recherche Européen) "Terres Cuites Architecturales et nouvelles méthodes de datation", the Universities of Bordeaux, Lyon and Rennes (France) and the Conseil Général du Maine-et-Loire. Christian Comte is also thanked for his contribution to this study. 


\section{REFERENCES}

Adamiec G and Aitken MJ, 1998. Dose-rate conversion factors: update, Ancient TL 16(2): 37-49.

Aitken MJ, 1985. Thermoluminescence Dating. Academic Press, London: $359 \mathrm{pp}$.

Bailiff IK and Holland N, 2000. Dating bricks of the last two millennia from Newcastle upon Tyne: a preliminary study. Radiation Measurements 32(5-6): 615-619, DOI 10.1016/S1350-4487(99)002863.

Bailiff IK, 2007. Methodological Developments in the Luminescence Dating of Brick from English Late-Medieval and Post-Medieval Buildings. Archaeometry 49(4): 827-851, DOI 10.1111/j.14754754.2007.00338.x.

Blain S, Guibert P, Bouvier A, Vieillevigne E, Bechtel F, Sapin C and Baylé M, 2007. TL-dating applied to building archaeology: The case of the medieval church Notre-Dame-Sous-Terre (Mont-SaintMichel, France). Radiation Measurements 42(9): 1483-1491, DOI 10.1016/j.radmeas.2007.07.015.

Blain S, Bailiff IK, Guibert P, Bouvier A and Baylé M, 2010. An intercomparison study of luminescence dating protocols and techniques applied to medieval brick samples from Normandy (France). Quaternary Geochronology 5(2-3): 311-316, DOI 10.1016/j.quageo.2009.02.016.

Cassen S, Lanos P, Dufresne P, Oberlin C, Delqué-Kolic E and Le Goffic M, 2009. Datations sur site (Tables des Marchands, alignement du Grand Menhir, Er Grah) et modélisation chronologique du néolithique morbihannais (Site dating (Tables des Marchands, alignment of the Grand Menhir, Er Grah) and chronological modelling of the Morbihanais Neolothic). In: Cassen S, ed., Autour de la Table, explorations archéologiques et discours savants sur une architecture restaurée à Locmariaquer, Morbihan (Table des Marchands et Grand Menhir), Colloque international de Vannes 2007. LARA, CNRS et Université de Nantes: 737-768 (in French).

Forsyth G H, 1953. The Church of St Martin at Angers. Princeton, University Press, London:

Gallo N, Fieni L, Martini M and Sibilia E, 1999. Building archaeology, ${ }^{14} \mathrm{C}$ and thermoluminescence: two examples comparison. Proceedings of "C14 et Archéologie »meeting, Suppl. Revue d'Archéométrie 1999 and Mémoires Société PréhistoriqueFrançaise XXVI: 425-431.

Gascoyne M, 1982. Geochemistry of the actinides and their daughters. In: Ivanovitch M and Harmon RS, Eds., Uranium series disequilibrium: applications to environmental problems. Clarendon Press, Oxford: 33-55.

Guibert P and Schvoerer M, 1991. TL dating: Low background gamma spectrometry as a tool for the determination of the annual dose. Nuclear Tracks Radiation Measurements 18(1-2): 231-238, DOI 10.1016/1359-0189(91)90117-Z.

Guibert P, Vartanian E, Bechtel F and Schvoerer M, 1996. Non-linear approach of TL response to dose: polynomial approximation. $A n-$ cient TL 14(2): 7-14.

Guibert P, Bechtel F and Schvoerer M, 1997. Déséquilibre des séries de l'uranium, implications sur la dose annuelle en datation par thermoluminescence: une étude à la Grotte XVI, Cénac et Julien, Dordogne (France) (Desequilibrium of the uranium series, impact on the dose rate in thermoluminescence dating : a study of the Cave XVI, Cénac et Julien, Dordogne (France)). Quaternaire 8: 377-389 (in French).
Guibert P, Ney C, Bechtel F, Schvoerer M and Araguas P, 1998. Datation par thermoluminescence d'éléments architecturaux en terre cuite de la «Seo del Salvador», cathédrale de Saragosse (Espagne) (Thermoluminescence dating of architectural ceramic features of the "Seo des Salvador" cathedral, Saragossa (Sapin)). Revue d'Archéométrie 22: 125-135 (in French).

Guibert P, Lahaye C and Bechtel F, 2009. The importance of U-series disequilibrium of sediments in luminescence dating: a case study at the Roc de Marsal cave (Dordogne, France). Radiation Measurements 44(3): 223-231, DOI 10.1016/j.radmeas.2009.03.024.

Lanos P, 2001, L'approche bayésienne en chronométrie : application à l'archéomagnétisme (Bayesian approach in chronometry: application to archaeomagnetism). In: Barrandon J-N, Guibert P, Michel V, Eds., Datation, XXIe rencontres internationales d'archéologie et d'histoire d'Antibes, Editions APDCA, Antibes: 113-139 (in French).

Lanos P, 2004, Bayesian inference of calibration curves, application to archaeomagnetism: Chapter 3 In: Buck CE and Millard AR, Eds., Tools for Constructing Chronologies, Crossing Disciplinary Boundaries, Series: Lecture Notes in Statistics: 177: 43-82. Springer-Verlag, London.

Mallet J, 1984. L'art Roman de l'Ancien Anjou (Romanesque art in ancient Anjou). Picard, Paris: 22-29 (in French).

Prigent D and Hunot JY, 2006. Saint-Martin d'Angers: des premières basiliques au site d'interprétation, L'église collégiale Saint-Martin (Angers, Maine-et-Loire) (St Martin's, Angers : from the first basilica to the site of interpretation). fascicule de présentation du site, Conseil général de Maine-et-Loire, Ministère de la Culture et de la Communication, Région Pays-de-Loire: 4-19 (in French).

Roque C, Guibert P, Dutine M, Vartanian E, Chapoulie R and Beechtel F, 2004. Dependance of luminescence characteristics of irradiated quartz with the thermal treatment and consequences for TL dating. Geochronometria 23: 1-8.

Sapin C, Baylé M, Büttner S, Guibert P, Blain S, Lanos P, Chauvin A, Dufresne P and Oberlin C, 2008, Archéologie du bâti et archéométrie au Mont-Saint-Michel, nouvelles approches de Notre-Dame-sous-Terre (Building archaeology and archaeometry in the Mont-saint-Michel, new approaches of Notre-Dame-sousTerre's church). Archéologie Médiévale, CNRS Editions, Paris, tome 38: 71-122 (in French).

Sanderson DCW, 1988. Fading of TL in feldspars: characteristics and corrections. Nuclear Tracks and Radiation Measurements 14(1-2): 155-161, DOI 10.1016/1359-0189(88)90057-X.

Tyler S and Mc Keever SWS, 1988. Anomalous fading of TL in oligoclase. Nuclear Tracks and Radiation Measurements 14(1-2): 149154, DOI 10.1016/1359-0189(88)90056-8.

Vieillevigne E, Guibert P and Bechtel F, 2007. Luminescence chronology of the medieval citadel of Termez, Uzbekistan: TL dating of bricks masonries. Journal of Archaeological Science 34(9): 14021416, DOI 10.1016/j.jas.2006.10.030.

Visocekas R, Spooner NA, Zink A, Blanc P, 1994. Tunnel afterglow, fading and infrared emission in thermoluminescence of feldspars. Radiation Measurements 23(2-3): 377-385, DOI 10.1016/13504487(94)90067-1.

Zink A, 1996. Thermoluminescence des feldspaths: Emission par effet tunnel et par thermoluminescence dans l'infra-rouge, incidences sur la datation des feldspaths (Feldspar thermoluminescence. Emission by tunnel effect and by thermoluminescence in infrared, impacts on feldspar dating). Doctorat des Universités Paris VII Denis Diderot et Bordeaux III Michel de Montaigne (in French). 